\title{
Interaction of Hemin and Hydrogen Peroxide: Effect of Media
}

\author{
Anton V. Lobanov, ${ }^{a}$ Sergey M. Vasiliev, ${ }^{\mathrm{b}}$ and Gennady G. Komissarov \\ ${ }^{a}$ Lomonosov Moscow State University, Chemistry Department, Moscow, 119991, Russia \\ ${ }^{\mathrm{b}}$ Goubkin Russian State University of Oil and Gas, Moscow, 119991, Russia \\ 'Semenov Institute of Chemical Physics, Russian Academy of Scienses, Moscow, 119991, Russia \\ @Corresponding authorE-mail: avlobanov@mail.ru
}

\begin{abstract}
Maximum of catalytic activity of hemin (complex of iron(III) with protoporphyrin IX, FePP) in hydrogen peroxide decomposition is shown to correspond to an associated form (evidently, dimer) of FePP. Influence of $\mathrm{NaHCO}_{3}, \mathrm{Na}_{2} \mathrm{HPO}_{4}$, cetyltrimethylammonium bromide and poly- $N$-vinylpyrrolidon on kinetics of hydrogen peroxide decomposition catalyzed by FePP and destruction of FePP was studied.
\end{abstract}

Keywords: Hemin, oxidative destruction, aggregation, hydrogen peroxide decomposition.

\section{Introduction}

Hemin ( $\mathrm{Fe}^{\mathrm{III}}$ complex of protoporphyrin IX, FePP) catalyses the decomposition of hydrogen peroxide. This process underlies the mechanism of action of oxidoreductases. ${ }^{[1]}$ Complex FePP isolated from apoenzyme is unstable in $\mathrm{H}_{2} \mathrm{O}_{2}$ systems. It is known that isolating of FePP from protein macromolecule results in decrease of the rate of $\mathrm{H}_{2} \mathrm{O}_{2}$ catalytic decomposition considerably. ${ }^{[2]}$ Both catalytic decomposition of $\mathrm{H}_{2} \mathrm{O}_{2}$ and oxidative destruction of FePP proceed simultaneously. Rate of these processes depends on aggregation state of FePP in solutions and changes in the presence of different compounds. At present the catalytic activity of FePP in $\mathrm{H}_{2} \mathrm{O}_{2}$ decomposition is well investigated. ${ }^{[2,3]}$ However insufficient attention are given to problem of stability of FePP in studied reaction systems containing $\mathrm{H}_{2} \mathrm{O}_{2}$.

In this work an influence of $\mathrm{NaHCO}_{3}, \mathrm{Na}_{2} \mathrm{HPO}_{4}$, cetyltrimethylammonium bromide (CTAB) and poly- $N$ vinylpyrrolidone (PVP) on interaction $\mathrm{FePP}$ and $\mathrm{H}_{2} \mathrm{O}_{2}$ in $0.1 \mathrm{~N} \mathrm{NaOH}$ was studied. Salts $\mathrm{NaHCO}_{3}$ and $\mathrm{Na}_{2} \mathrm{HPO}_{4}$ are components of different buffer solutions and important constituent part of biological liquids. Micellar systems of CTAB and composition based on PVP are widely applied in pharmacology and biophysical modeling, for instance as solubilization agents. The question about association of FePP in these systems is of the particular interest.

\section{Experimental}

Hydrogen peroxide without stabilizers, chlorinated FePP, $\mathrm{Na}_{2} \mathrm{HPO}_{4}, \mathrm{NaHCO}_{3}, \mathrm{NaOH}, \mathrm{CTAB}$ («Reakhim», Russia) and PVP with average molecular weight $10000 \mathrm{~g} / \mathrm{mol}$ («Sigma», USA) were used in experiment. Salts, CTAB or PVP were added to $50 \mathrm{ml}$ of solution FePP of known concentration in $0.1 \mathrm{~N} \mathrm{NaOH}$. Then $\mathrm{H}_{2} \mathrm{O}_{2}$ was added to concentration $0.08 \mathrm{M}$ at stirring. Concentration of $\mathrm{H}_{2} \mathrm{O}_{2}$ was determined by chemical titration using potassium permanganate. Concentration of FePP in solutions was calculated on value of their optical density in Soret band measured on spectrophotometer Beckman DU-8B using quartz cells $(1 \mathrm{~cm})$.

\section{Results and Discussion}

The rate of $\mathrm{H}_{2} \mathrm{O}_{2}$ decomposition catalyzed by FePP was determined from initial part of kinetic curves. Dependence of the rate of $\mathrm{H}_{2} \mathrm{O}_{2}$ decomposition (w) on FePP concentration is characterized by maximum corresponding $4.5 \cdot 10^{-4}$ M FePP (Figure 1). It was interesting to study an aggregation state of FePP in dependence on its concentration. The graph of change of optical density of FePP solutions in 0.1 $\mathrm{N} \mathrm{NaOH}$ depending on FePP is represented in Figure 2. The straight line showing the Bouguer law on Figure 2 (value of molar extinction of FePP is $90000 \mathrm{l} / \mathrm{mol} \cdot \mathrm{cm}^{[4]}$ ) coincides with the straight line constructed by least-squares method through points in the range of concentration $(0.3-1.5) \cdot 10^{-5} \mathrm{M}$. At the concentration of FePP $\geq 2 \cdot 10^{-5} \mathrm{~mol} / 1$ a deviation from Bouguer law is observed (Figure 2). This feature testifies to process of FePP association, first of all FePP dimer formation..$^{[5]}$

As it was reported earlier, ${ }^{[6,7]} \mathrm{Fe}^{\mathrm{III}}$ porphyrins interact with $\mathrm{H}_{2} \mathrm{O}_{2}$ forming a particle of ferryl type. In this case its formula is $\mathrm{PPFe}^{\mathrm{IV}}=\mathrm{O}$. This particle is highly reactive. First

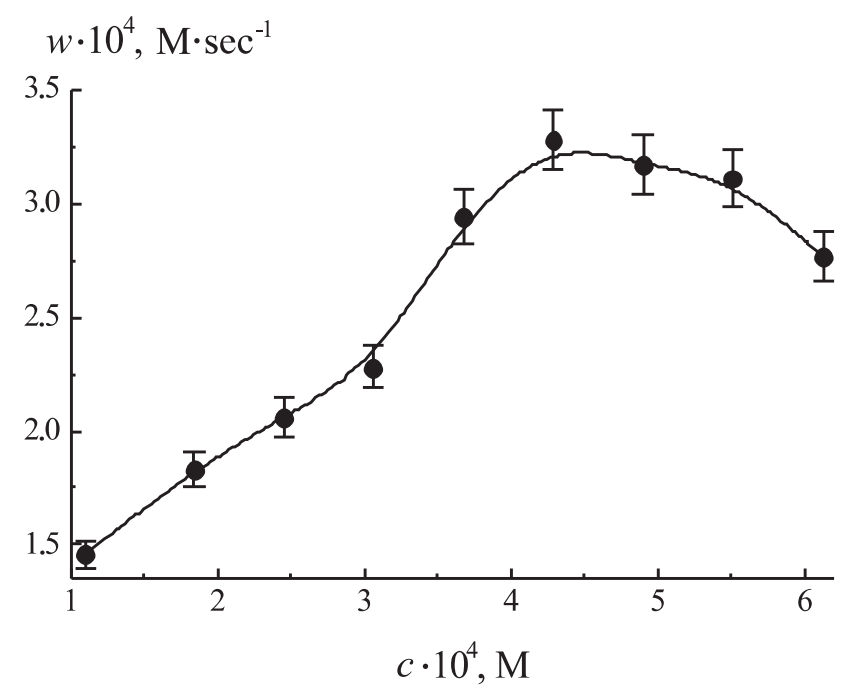

Figure 1. Dependence of rate of $\mathrm{H}_{2} \mathrm{O}_{2}$ decomposition on FePP concentration. 


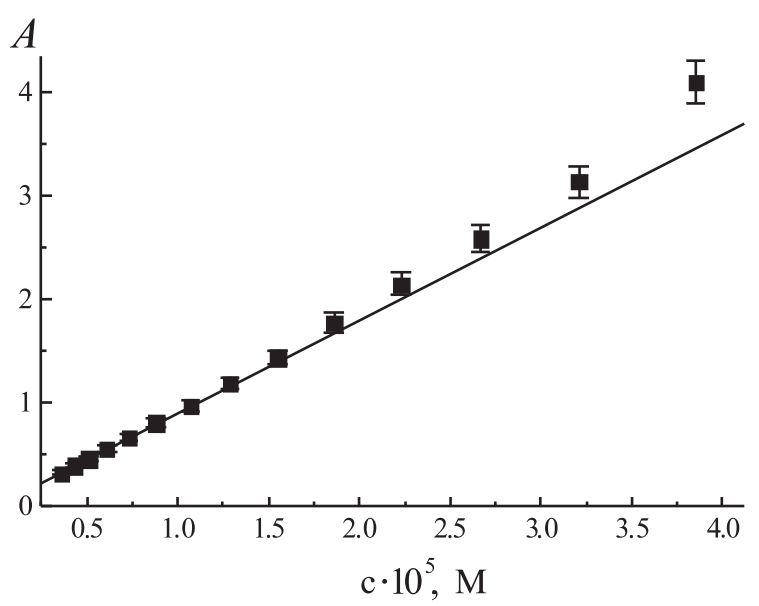

Figure 2. Dependence of optical density of FePP solutions on their concentration.

of all FePP complex is subjected to oxidative destruction by ferryl transients. Particles $\mathrm{PPFe}^{\mathrm{IV}}=\mathrm{O}$ are easily formed, if complex FePP is in the monomer form. In dimer state generation of less active $\mu$-oxodimers $\left(\mathrm{PPFe}^{\mathrm{III}}\right)_{2} \mathrm{O}$ competes to $\mathrm{PPFe}^{\mathrm{IV}}=\mathrm{O}$ formation. Consequently $\mathrm{FePP}$ in dimer form oxidizes and is spent as the catalyst to a smaller extent.

The given feature of interaction $\mathrm{FePP}$ and $\mathrm{H}_{2} \mathrm{O}_{2}$ allows to explain the decrease of the rate of $\mathrm{H}_{2} \mathrm{O}_{2}$ decomposition catalyzed by FePP at addition of cationic surfactant CTAB (Figure 3).



Figure 3. Kinetics of $\mathrm{H}_{2} \mathrm{O}_{2}$ decomposition catalyzed by FePP in $0.1 \mathrm{~N} \mathrm{NaOH}$ without additives (1), in the presence of $0.1 \mathrm{M}$ $\mathrm{NaHCO}_{3}(2), 0.1 \mathrm{M} \mathrm{Na}_{2} \mathrm{HPO}_{4}$ (3), $3 \mathrm{mM} \mathrm{CTAB}$ (4) and $0.5 \mathrm{mM}$ PVP (5).

Addition of CTAB ( $3 \mathrm{mM})$ lowers process of FePP dimer formation because FePP molecule contains negatively charged propionic acid residues in alkaline solutions. So FePP destruction accelerates in these systems (Figure 4).

Formation of $\mathrm{PPFe}^{\mathrm{IV}}=\mathrm{O}$ is facilitated in the presence of acceptors of $\mathrm{O}^{2-}$ anions, ${ }^{[6]}$ as well as at decrease of $\mathrm{pH}$. In the presence of the salts $\mathrm{Na}_{2} \mathrm{HPO}_{4}$ and $\mathrm{NaHCO}_{3}(0.1 \mathrm{M})$ leading to the reduction of $\mathrm{pH}$ value $\mathrm{FePP}$ destruction increases (Figure 4). Hence the decrease of the rate of $\mathrm{H}_{2} \mathrm{O}_{2}$ decomposition is observed (Figure 3 ). However it is visible that FePP destruction does not allow to explain the decrease of the rate of $\mathrm{H}_{2} \mathrm{O}_{2}$ decomposition fully. For instance, the decrease of the rate of $\mathrm{H}_{2} \mathrm{O}_{2}$ decomposition in $\mathrm{NaHCO}_{3}$ solution is not explained by lesser concentration of destructed FePP. We assume that

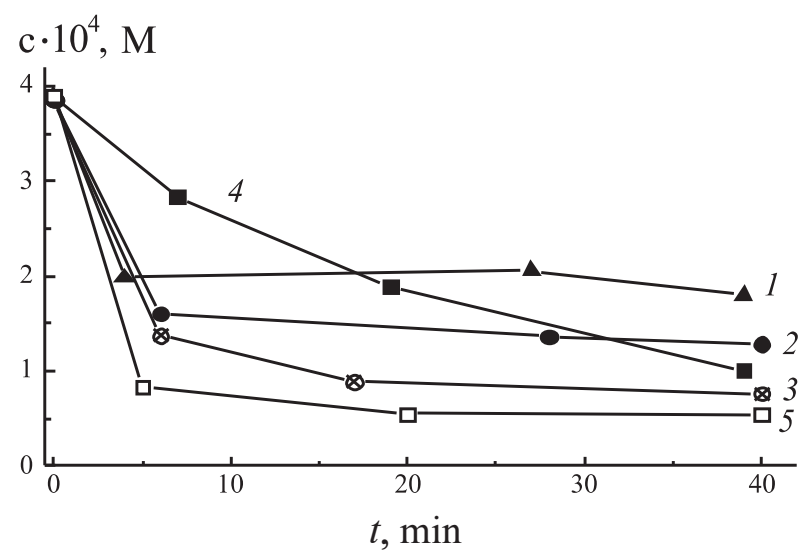

Figure 4. Decrease of FePP concentration during interaction with $\mathrm{H}_{2} \mathrm{O}_{2}$ in $0.1 \mathrm{~N} \mathrm{NaOH}$ without additives (1), in the presence of $0.1 \mathrm{M} \mathrm{NaHCO}_{3}$ (2), $0.1 \mathrm{M} \mathrm{Na}_{2} \mathrm{HPO}_{4}$ (3), $3 \mathrm{mM} \mathrm{CTAB}$ (4) and $0.5 \mathrm{mM}$ PVP (5).

deceleration of $\mathrm{H}_{2} \mathrm{O}_{2}$ decomposition in bicarbonate solution is caused also by formation of peroxocarbonates, ${ }^{[8]}$ which are relatively stable concerning FePP catalysis.

Strengthening of FePP interaction with $\mathrm{H}_{2} \mathrm{O}_{2}$ occurs also at addition of water-soluble polymer PVP to solution (0.5 mM) (Figure 4). Binding of FePP complexes with PVP macromolecules obviously results in being of FePP mainly in a monomer state. Destruction of FePP increases in this case. At the same time it is known that PVP absorbs 50-60\% $\mathrm{H}_{2} \mathrm{O}_{2}$ on weight. ${ }^{[9,10]}$ So combined coordination of $\mathrm{H}_{2} \mathrm{O}_{2}$ and FePP is possible. Therefore rate of decay $\mathrm{H}_{2} \mathrm{O}_{2}$ decomposition practically does not decrease.

\section{Conclusions}

Studied additives influence on aggregation states of hemin and decrease the rate of $\mathrm{H}_{2} \mathrm{O}_{2}$ decomposition catalyzed by hemin. However a strict correlation of this effect with FePP destruction is not observed because there are specific action of each systems, e.g. peroxocarbonates formation from $\mathrm{HCO}_{3}^{-}$, significant binding of $\mathrm{H}_{2} \mathrm{O}_{2}$ by PVP macromolecules and others. Observable features of interaction FePP and $\mathrm{H}_{2} \mathrm{O}_{2}$ in the presence of various compounds are necessary to consider at discussion of $\mathrm{H}_{2} \mathrm{O}_{2}$ role in biological processes, and also by working out of the artificial systems modeling these processes.

Acknowledgements. This work was supported by RAS Presidium program P-15 «Life origin and geo-biological systems evolution».

\section{References}

1. Berezin B.D., Berezin D.B. Kurs Sovremennoy Organicheskoy Khimii [A Course of the Modern Organic Chemistry]. Moscow: Vysshaya Shkola, 1999, 746 p. (in Russ).

2. Komissarov G.G. Fotosintez: Fiziko-Khimicheskiy Podkhod [Photosynthesis: Physique-Chemical Approach]. Moscow: URSS, 2003, 224 p. (in Russ).

3. Komissarov G.G. Russ. J. Chem. Phys. 2003, 1, 24 (in Russ).

4. Doson R., Elliot D., Elliot U., Jones K. Spravochnik Biokhimika [The Biochemist's Handbook]. Moscow: Mir, 1991, 189 p. (in Russ). 
Interaction of Hemin and Hydrogen Peroxide

5. Golovina I.V., Vasiliev V.V. Koord. Khim. 1998, 24, 438 (in Russ).

6. Sychev A.Ya., Isak V.G. Uspekhi Khimii 1995, 64, 1183 (in Russ).

7. Silaghi-Dumitrescu R. Macroheterocycles 2008, 1, 79-81.

8. Firsova T.P., Molodkina A.N., Morozova T.G. NeorganicheskiePerekisnye Soedineniya [NeorganicPeroxide Compounds]. Moscow: Nauka, 1975, 101 p. (in Russ).

9. Panarin E.F., Kalnin'sh K.K., Pestov D.V. Doklady Academii Nauk 1998, 363, 208 (in Russ).

10. Lobanov A.V., Nevrova O.V., Vedeneeva Yu.A., Golovina G.V., Komissarov G.G. Photodestruction of Chlorophyll in Non-biological Systems. In: Modern Tendencies in Organic and Bioorganic Chemistry. Today and Tomorrow. (Mikitaev A., Ligidov M.K., Zaikov G.E., Edrs.). New-York: Nova Science Publishers, Inc., 2008, 165-169.

Received 16.05.2009 Accepted 10.06.2009 